\title{
The Performance of Knowledge Transfer in University
}

\author{
SITI NUR AZIZAH ${ }^{1}$, DANI RIZANA ${ }^{2}$, PARMIN $^{3}$ \\ ${ }^{1}$ Management, UNIVERSITAS PUTRA BANGSA, INDONESIA. E-mail:sitinuraziz@yahoo.com \\ ${ }^{2}$ Management, UNIVERSITAS PUTRA BANGSA, INDONESIA. E-mail: danirizana@gmail.com \\ ${ }^{3}$ Management, UNIVERSITAS PUTRA BANGSA, INDONESIA. E-mail:par-kbm@yahoo.com
}

\begin{abstract}
The aim of this study is expected to be able to answer the research problem is how to improve the performance of knowledge transfer in the university. The sampling technique used in this study is the purposive sampling method. This manner takes 100 samples with a specific set of criteria education staff with a bachelor's degree in five colleges located in Kebumen District, Center Java, Indonesia. The result of the data processing with SPSS 25 shows that part, the quality of human resource management and information technology competence had a positive effect on the quality of knowledge assets. The result showed that the quality of knowledge assets had positive effects on the performance of knowledge transfer. Finally, quality of knowledge assets roles as an intervening variable in this research
\end{abstract}

Keywords: Performance of knowledge transfer; The quality of human resource management; Quality of knowledge assets; Information technology competence.

JEL Classification: M12, M10, M19 


\title{
El Rendimiento de la Transferencia de Conocimientos en la Universidad
}

\author{
SITI NUR AZIZAH ${ }^{1}$, DANI RIZANA ${ }^{2}$, PARMIN ${ }^{3}$ \\ ${ }^{1}$ Management, UNIVERSITAS PUTRA BANGSA, INDONESIA. E-mail:sitinuraziz@yahoo.com \\ ${ }^{2}$ Management, UNIVERSITAS PUTRA BANGSA, INDONESIA. E-mail: danirizana@gmail.com \\ ${ }^{3}$ Management, UNIVERSITAS PUTRA BANGSA, INDONESIA. E-mail:par-kbm@yahoo.com
}

\begin{abstract}
RESUMEN
El objetivo de este estudio es poder responder al problema de investigación es cómo mejorar el rendimiento de la transferencia de conocimientos en la universidad. La técnica de muestreo utilizada en este estudio es el método de muestreo intencional. De esta manera se toman 100 muestras con un conjunto específico de criterios del personal de educación con una licenciatura en cinco colegios ubicados en el distrito de Kebumen, Java Central, Indonesia. El resultado del tratamiento de los datos con el SPSS 25 muestra que, en parte, la calidad de la gestión de los recursos humanos y la competencia en tecnologías de la información tuvieron un efecto positivo en la calidad de los activos de conocimiento. El resultado mostró que la calidad de los activos de conocimiento tuvo efectos positivos en el rendimiento de la transferencia de conocimientos. Por último, la calidad de los activos de conocimiento desempeña un papel de variable interviniente en esta investigación.
\end{abstract}

Palabras clave: Rendimiento de la transferencia de conocimientos; Calidad de la gestión de los recursos humanos; Calidad de los activos de conocimiento; Competencia en tecnologías de la información.

Clasificación JEL: M12, M10, M19 


\section{Introduction}

The transfer of knowledge within an organization can have a large influence on the development of an organization. Every approach taken to solve a problem or operational skills requires proper knowledge. Knowledge transfer is very important for the progress of the organization. (Argote et al., 2003) says that knowledge transfer is the communication of knowledge from the source so that it is learned and applied by the recipient. Sources and recipients can be individuals, groups, teams, organizational units, or the entire organization. Knowledge sharing is a process where individual exchanges knowledge and ideas through discussions to create new knowledge or ideas (Van Den Hooff \& De Ridder, 2004). Knowledge sharing could help employees to understand their jobs better and bring personal recognition within the department (Cheng et al., 2009)

The knowledge transfer stage can be said to be the most difficult stage carried out in the knowledge management process. Sometimes individuals who have competence or knowledge are reluctant to transfer their knowledge for fear of losing their competitive value in the organization. In addition to transferring knowledge, knowledge of communication is needed, making it difficult for individuals who have the willingness to transfer the knowledge they have but do not understand how to communicate that knowledge effectively. Managers also find it difficult to design an organization that can share knowledge efficiently

(Perri, 2006) states the transfer of knowledge in organizations must involve transfers at the individual level because individuals contribute a lot to the organization it is necessary to understand how knowledge can be transferred between individuals and recognize methods of knowledge transfer. It is important that effective knowledge management activity for the organization. The transfer of knowledge developed in organizations strengthens the relationship between knowledge transfer and business strategy, following the culture of the organization as a whole, following leadership, humans with social networks, and institutionalizing the discipline of learning. Espinosa and Dobon (2011) suggest a positive effect of employee management on knowledge transfer

Effective knowledge transfer can be achieved through formal systems and transfers through human behavior in the organizational environment. (Narasimha, 2000) states that the quality of knowledge assets is influenced by human resources and information technology. Resource-based perspectives increasingly emphasize that the role of organizational knowledge plays a role in maintaining a company's competitive advantage. This research is an initial effort to develop a framework that will assist in conducting a systematic study into the role of organizational knowledge that can play a role in ensuring the maintenance of competitive advantage

The problem of knowledge transfer in public organizations such as universities faces unusual challenges. A public organization is an organization with a type that has a hierarchy and bureaucracy that makes it difficult to share knowledge. Some people are reluctant to share knowledge because they maintain knowledge for themselves, for example when they experience promotions and this is a paradigm of power (Liebowitz \& Yan, 2004). Based on the research gap this is the main reason for researchers to examine more deeply the components that affect the performance of knowledge transfer at the university.

\section{Literature Review and Hypothesis}

\subsection{The quality of human resource management (HRM) and the quality of knowledge assets (QKA)}

QHRM shows employee perceptions about human resource management activities (Syed-Ikhsan \& Rowland, 2004) (Swart \& Kinnie, 2003) examines how human resource practices are used to manage knowledge assets, human resource management is implemented to develop knowledge assets with special characteristics, for example, human capital. (McCuiston \& Jamrog, 2005) states that a responsive and flexible knowledge management system, an organizational culture that encourages, engages, and shares knowledge, and provides open access to knowledge across the organization and collaboration determines the successful implementation of a knowledge management system and also 
depends on the design that results in a responsive and adaptive organization. Human resource management must be able to play a strategic role in competitive advantage in a context where organizations depend on individuals and collective knowledge assets.

Based on the description above, the hypothesis is formulated as follows:

$\mathrm{H} 1$ : The higher the quality of HRM in university, the higher the quality of knowledge asset

\subsection{Information technology competency (ITC) and quality of knowledge assets (QKA)}

Mastery of information technology is the employee's perception of the benefits and use of information technology (Syed-Ikhsan \& Rowland, 2004) Knowledge transfer has interactions between experts who are supported by technology (Wilkesmann \& Wilkesmann, 2011)). Alavi, et.al (2001) states that knowledge management systems that utilize various information technology tools can support the process of knowledge management in organizations. Sveiby (1996; Bender, et.al (2000) states that information technology must be seen as a necessary tool, but technology and its use will not necessarily support knowledge management or knowledge assets. Other studies by Syed-lhsan and Rowland (2004) produce conclusions that information technology has a significant influence on knowledge assets Information technology has been widely used in the effective management of knowledge assets by facilitating knowledge sharing and learning among workers Zhang (2005). SyedIhsan and Rowland (2004) produce the conclusion that information technology has a significant effect on knowledge assets.

We formulated a hypothesis as follows:

$\mathrm{H} 2$ : The higher the competency of information technology in university, the higher the quality of knowledge assets

\subsection{Quality of HRM (QHRM) and knowledge transfer performance (KTP)}

Espinosa and Dobo'n (2011) suggest the positive influence of employees on the transfer of knowledge. Psarras (2006) revealed that knowledge management can contribute to the development of education and training in the context of a new era of the knowledge-based economy. HRM practices consisting of staffing, training, promotion, compensation, and rewards have a large and positive effect on knowledge transfer (Minbaeva, 2005). Training and development, recruitment and selection, teamwork, and performance appraisal are positively related to knowledge sharing (Yang Fong et.al, 2011).)

We formulated a hypothesis as follows:

H3: The higher the quality of human resource management in university, the higher the performance of knowledge transfer

\subsection{Information technology competence (ITC) and knowledge transfer performance (KTP)}

Knowledge transfer has interactions between experts supported by technology (Wilkesmann and Wilkesmann 2011). Alavi, et.al (2001) states that knowledge management systems that utilize various information technology tools can play a role in supporting the knowledge management process in organizations. Technology can increase the efficiency of knowledge transfer by increasing the speed of transfer and reducing costs in this case time and distance (Albino et al., 2004). (Syed-Ikhsan \& Rowland, 2004) concluded that the infrastructure of information technology increases the performance of individual knowledge transfer. There is a positive relationship between the infrastructure of information and communication technology and the transfer of knowledge. Research (Rhodes et al., 2008) concluded that information technology systems have the most significant impact on knowledge transfer. Centralized storage and retrieval of information are very important for knowledge management (Ray, 2008). (Zhang, 2005) states that the degree of satisfaction of the organization achieved through the technology used not only increases profits but also affects the transfer of knowledge. 
Based on the description above, the hypothesis is formulated as follows:

$\mathrm{H} 4$ : The higher the competency of information technology in university, the higher the performance of knowledge transfer

\subsection{Quality of knowledge assets (QKA) and knowledge transfer performance (KTP)}

Quality of knowledge assets is the employee's perception of explicitly managed knowledge assets that support organizational decision making and action Knowledge assets allow knowledge to be transferred to the right people and at the right time with high Accu (Bloodgood \& Salisbury, 2001). The performance of knowledge transfer depends on the availability and accessibility of knowledge assets. (Syed-Ikhsan \& Rowland, 2004) concluded that the availability of knowledge assets in organizations has a direct influence on the performance of knowledge transfer in organizations. (McGill, 2006) states qualitatively and quantitatively the relationship between types of intellectual capital and effective knowledge mechanisms to transfer knowledge. (Seleim \& Khalil, 2011) concluded that intellectual capital influences knowledge acquisition and knowledge transfer.

We formulated a hypothesis as follows:

H5: The higher the quality of knowledge assets in university, the higher the performance of knowledge transfer.

Based on the hypothesis, the research model is as follows:

Figure 1 The conceptual model

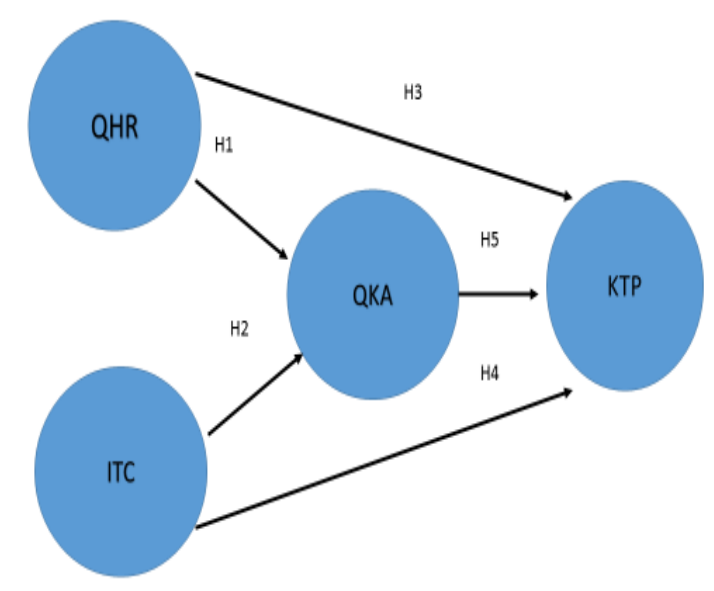

QHRM : Quality of human resources management

ITC: Information technology competency

QKA: Quality of knowledge assets

KTP: Knowledge transfer performance

\section{Methodology}

The population in this study were employees in five colleges which are located in Kebumen district, Central Java, Indonesia. This study applied a purposive sampling technique, which is for Staff education with a minimum education of bachelor. This survey was conducted for approximately 2 months during October-November 2020. Some 115 questionnaires were distributed, 100 were completed and adequately filled. Thus, the response rate for this study is $87 \%$. The respondent characteristics were as follows: mostly females, i.e., as many as 67 of the sample (67\%), aged less than 40 years ( 85 people, i.e., $85 \%$ ), married ( 87 people, i.e., $87 \%$ ), finished a master degree (99 people, i.e., $99 \%$ ) and with tenure of fewer than 5 years ( 87 people, i.e., $87 \%$ ). 


\subsection{Measurement}

The purpose of this study was to examine the effect of quality in HRM and information technology competence on knowledge transfer performance through knowledge asset quality as a mediator. The instrument is a 5 -point Likert scale ( $1=$ strongly bad; $5=$ strongly good) The quality of human resource management will be measured by four items namely recruitment and selection, employee placement, and employee training and development and cooperation (Syed-Ikhsan \& Rowland, 2004)Information technology competence is measured using five items adapted from the research of (Syed-lkhsan \& Rowland, 2004), namely the ability to control information technology, the ease of using information technology, the speed in using information technology, the ability to process data, and the ability to process information. Asset knowledge quality is measured using five-term: increase employee competency, increase understanding of work procedures, increase understanding of how to do work and increase the use of relevant documents, understand communication flow. Knowledge transfer performance is measured using five indicators namely, the speed of knowledge transfer, the reliability of knowledge transfer, the accuracy of the content of knowledge transfer, the timeliness of knowledge transfer, and the relevance of knowledge transfer (Zhang, 2005). The reliability coefficient of the original overall scale was 0.7

\section{Results and Discussion}

Cronbach-alpha analysis can be used to determine internal consistency. The reliability coefficient in this study started from 0.7 and above as the standard for receiving the items used in the questionnaire. In table 1 all the variables in this study meet the internal consistency which is calculated based on the number of subjects involved in the study. The HR quality scale has a Cronbach-alpha value of 0.79 , information technology competence 0.82 , knowledge assets 0.88 , and knowledge transfer performance 0.82 .

Table 1 Reliability test

\begin{tabular}{|l|c|}
\hline \multicolumn{1}{|c|}{ Item } & $\begin{array}{c}\text { Cronbach-alpha } \\
\text { values }\end{array}$ \\
\hline Quality Of HRM & 0.79 \\
\hline Information Technology Competency & 0.82 \\
\hline Knowledge Asset & 0.88 \\
\hline Transfer Knowledge Performance & 0.82 \\
\hline
\end{tabular}

The item validity was computed the Pearson correlation showed all item has a significant value, correlation is significant at the 0.05 level (table 2 ).

Table 2 Validity test

\begin{tabular}{|l|l|l|l|}
\hline \multirow{2}{*}{ Item } & \multicolumn{2}{l|}{$\begin{array}{l}\text { Pearson } \\
\text { correlation }\end{array}$} & sig \\
\hline \multirow{2}{*}{ Quality HRM } & The quality of recruitment and selection & 0,578 & 0.000 \\
\cline { 2 - 4 } & The quality of placement & 0.684 & 0.000 \\
\cline { 2 - 4 } & The quality of training and development & 0.813 & 0.000 \\
\cline { 2 - 4 } & The quality of cooperation & 0.678 & 0.000 \\
\hline $\begin{array}{l}\text { information } \\
\text { technology } \\
\text { competency }\end{array}$ & The ability to control information technology & 0.580 & 0.000 \\
\hline & & & \\
\hline & the ease of using information technology in an organization & 0.690 & 0.000 \\
\hline & speed in using information technology & 0.800 & 0.000 \\
\hline $\begin{array}{l}\text { Quality } \\
\text { Knowledge } \\
\text { Assets }\end{array}$ & the ability to process information & 0.75 & 0.000 \\
\hline & increased employee competency & 0.70 & 0.000 \\
\hline & & 0.690 & 0.000 \\
\hline & understanding of work procedures & & \\
\hline
\end{tabular}




\begin{tabular}{|l|l|l|l|}
\hline & increased understanding of how to do work & 0.718 & 0.000 \\
\hline & increased use of relevant documents & 0.708 & 0.000 \\
\hline $\begin{array}{l}\text { Knowledge } \\
\text { transfer } \\
\text { performance }\end{array}$ & Understanding of communication flow & 0.614 & 0.000 \\
\hline & the speed of knowledge transfer & 0.640 & 0.000 \\
\hline & $\begin{array}{l}\text { the accuracy of the content of knowledge transfer } \\
\text { the timeliness of knowledge transfer }\end{array}$ & 0.757 & 0.000 \\
\hline & the relevance of knowledge transfer & 0.650 & 0.000 \\
\hline
\end{tabular}

Hypothesis testing is presented in the table below

Table 3 Regression test structure 1

\begin{tabular}{|c|c|c|c|c|c|c|}
\hline & \multirow{2}{*}{ Model } & \multicolumn{2}{|c|}{$\begin{array}{l}\text { Unstandardized } \\
\text { Coefficients }\end{array}$} & \multirow{2}{*}{$\begin{array}{c}\text { Standardized } \\
\text { Coefficients } \\
\text { Beta }\end{array}$} & \multirow[t]{2}{*}{$t$} & \multirow[t]{2}{*}{ Sig. } \\
\hline & & B & Std. Error & & & \\
\hline \multirow[t]{3}{*}{1} & (Constant) & 3.979 & 1.010 & & 3.939 & .000 \\
\hline & X1 (QHRM) & .731 & .109 & .603 & 6.685 & .000 \\
\hline & X2 (ITC) & .181 & .083 & .196 & 2.177 & .032 \\
\hline
\end{tabular}

Hypothesis 1 showed (Table 3 ) that assets knowledge management is influenced by the variable QHRM (t count 6.685 sig $0.000: \mathrm{H} 1$ accepted). These results show that the better the quality of human resources management, the higher the quality of knowledge assets at the university. The better the quality of recruitment and selection, quality of placement, quality of training and development and quality of cooperation at universities, the better quality of knowledge assets

Hypothesis 2 showed (Table 3) that assets knowledge management is influenced by the variable ITC (t count 2.177 sig 0.000: $\mathrm{H} 2$ accepted) These results show that the better the information technology competency, the higher the quality of knowledge assets at the university. The better the ability to control information technology, ease of using information technology in an organization, speed in using information technology, ability to process data, ability to process information at the university, the better the better quality of knowledge assets.

The results of this study are reinforced by the opinion that the practice of human resource management consisting of staffing, training, promotion, compensation, and rewards has a large and positive effect on knowledge transfer (Minbaeva et al., 2003) Human resource management must be able to play a strategic role in competitive advantage in a context where organizations depend on individuals and collective knowledge assets (Swart \& Kinnie, 2003)

Table 4 Regression test structure 2

\begin{tabular}{|c|c|c|c|c|c|c|}
\hline & \multirow[t]{2}{*}{ Model } & \multicolumn{2}{|c|}{$\begin{array}{l}\text { Unstandardized } \\
\text { Coefficients }\end{array}$} & $\begin{array}{c}\text { Standardized } \\
\text { Coefficients }\end{array}$ & \multirow[t]{2}{*}{$\mathrm{T}$} & \multirow[t]{2}{*}{ Sig. } \\
\hline & & B & Std. Error & Beta & & \\
\hline \multirow[t]{4}{*}{1} & Constant & 6.107 & 1.362 & & 4.483 & .000 \\
\hline & ITC & .230 & .089 & .269 & 2.586 & .011 \\
\hline & QHRM & .275 & .120 & 312 & 2.868 & .045 \\
\hline & QAK & .304 & .116 & .398 & 3.768 & .030 \\
\hline
\end{tabular}

Hypothesis 3 testing on structure 2 (table 4) showed the transfer knowledge performance is influenced by the variable quality of human resource management ( $t$ count 2.868 sig $0.045 \mathrm{H3}$ 
accepted). These results show that the better the quality of human resource management, the higher the transfer knowledge performance at the university what can be done by increasing quality of recruitment and selection, quality of placement, quality of training and development and quality of cooperation.

Hypothesis 4 testing on structure 2 (table 4) showed the variable of information technology competence affected transfer knowledge performance (t count 2.586 sig $0.000 \mathrm{H} 4$ accepted). These results show that the better information technology competence, the higher the transfer knowledge performance at the university.

Hypothesis 5 testing on structure 2 (table 4 ) showed the quality knowledge assets have a significant effect on transfer knowledge performance (t count 3.768 sig $0.030 \mathrm{H} 5$ accepted). These results show that the better quality knowledge assets, the higher the transfer knowledge performance at the university

The result of this study support (Cheng et al., 2009) on studies conducted at universities in Malaysia. The quality of recruitment and training carried out by universities affects the performance of knowledge transfer. The ease of using information technology in an organization and the ability to control information technology enable universities to improve their performance.

This study uses simple mediation or simple mediation with one intermediate variable. Basically, there are several ways to determine whether a variable is intervening, namely theoretically and statistically. First, theoretically, as stated by MacKinnon (2008) that most mediators are determined based on a theory where the variables are interconnected. In this study, citing Bryant and Zillman (2002) regarding Social Cognitive Theory, that most external influences will affect behavior through cognition first. From this statement, it can be understood that the quality of knowledge assets can be an intervening/mediator variable. The level of knowledge fulfills the assumption as a theoretical intervening variable. The mediating effect of quality of knowledge assets supports the results of research conducted by (Syed-Ikhsan \& Rowland, 2004) on public companies in Malaya. Formal procedures in carrying out work must continue to be properly supervised. The role of quality of knowledge assets is very important to improve the performance of knowledge transfer in universities because the bureaucratic structure at universities is usually filled with young people who are dynamic and easy to develop.

The result of this study support Joanne (2000) on studies conducted at a multinational organization. Increased employee competency and understanding of how to do work will increase the accuracy of the content of knowledge transfer in university. Information technology competencies also have a positive and significant effect on the quality of knowledge assets. According to (Zhang, 2005) information technology has been widely used in the effective management of knowledge assets by facilitating the sharing of knowledge and learning among staff

Any approach taken to solve problems or operations skills will be reinvented and requires proper knowledge so the role of knowledge transfer becomes very important. Knowledge transfer is the main focus of learning that is very important for the progress together with an organization. Knowledge transfer is a communication of knowledge from the source so that it is learned and applied by the recipient (Darr \& Kurtzberg, 2000).

The practical implication of this finding is that university management continues to improve the formal system of knowledge transfer by continuously training human resources, good payroll system and trusted recruitment system so that quality of knowledge assets can be continuously improved. Thus the behavior of human resources at the university can be managed and become a source of excellence. Formal procedures will make the system run well and the transfer of knowledge will increase its performance

\section{Conclusion}

Knowledge is an organizational asset which, if managed properly, will be of value if managed properly. In organizational theory, technology has an important role in determining organizational 
design. Because of its wide reach, it is possible for universities to manage information with adequate quality human resources. This will create innovation as well as being important in the value creation process.

Organizational excellence is also determined by its ability to transfer knowledge that is difficult to imitate. The essence of a knowledge asset is that it can create value so that it becomes a continuous advantage for the university. Knowledge transfer involves the management of competent human resources through the management of superior human resources in the organization through good HR practices.

\section{Limitations and Suggestions for Future Research}

New possible contributions to future research can emerge from the limitations of the study. The causal relationship cannot be proven by cross section design. A longitudinal design is needed for further research, although it does not completely solve the difficulty of proving a causal relationship (Carmeli \& Spreitzer, 2009).

\section{References}

1. Albino, V., Garavelli, A. C., \& Gorgoglione, M. (2004). Organization and technology in knowledge transfer. Benchmarking: An International Journal.

2. Argote, L., McEvily, B., \& Reagans, R. (2003). Managing knowledge in organizations: An integrative framework and review of emerging themes. Management Science, 49(4), 571-582.

3. Bloodgood, J. M., \& Salisbury, W. D. (2001). Understanding the influence of organizational change strategies on information technology and knowledge management strategies. Decision Support Systems, 31(1), 55-69.

4. Carmeli, A., \& Spreitzer, G. M. (2009). Trust, connectivity, and thriving: Implications for innovative behaviors at work. The Journal of Creative Behavior, 43(3), 169-191.

5. Cheng, M.-Y., Ho, J. S.-Y., \& Lau, P. M. (2009). Knowledge sharing in academic institutions: A study of multimedia university Malaysia. Electronic Journal of Knowledge Management, 7(3).

6. Liebowitz, J., \& Yan, C. (2004). Knowledge sharing proficiencies: the key to knowledge management. In Handbook on Knowledge Management 1 (pp. 409-424). Springer.

7. McCuiston, V. E., \& Jamrog, J. J. (2005). Knowledge management implementation: HR executives speak out. Journal of Applied Management and Entrepreneurship, 10(1), 20.

8. McGill, T. P. (2006). Harnessing intellectual capital: A study of organizational knowledge transfer. Touro University International.

9. Minbaeva, D., Pedersen, T., Björkman, I., Fey, C. F., \& Park, H. J. (2003). MNC knowledge transfer, subsidiary absorptive capacity, and HRM. Journal of International Business Studies, 34(6), 586-599.

10.Perri, M. (2006). The drama of knowledge transfer in a merger environment: a case study. Concordia University.

11.Ray, L. L. (2008). Requirement for knowledge management: business driving information technology. Journal of Knowledge Management.

12.Rhodes, J., Lok, P., Hung, R. Y., \& Fang, S. (2008). An integrative model of organizational learning and social capital on effective knowledge transfer and perceived organizational performance. Journal of Workplace Learning.

13.Seleim, A. A. S., \& Khalil, O. E. M. (2011). Understanding the knowledge management-intellectual capital relationship: a two-way analysis. Journal of Intellectual Capital.

14.Swart, J., \& Kinnie, N. (2003). Sharing knowledge in knowledge-intensive firms. Human Resource Management Journal, 13(2), 60-75.

15.Syed-Ikhsan, S. O. S., \& Rowland, F. (2004). Knowledge management in a public organization: a study on the relationship between organizational elements and the performance of knowledge transfer. Journal of Knowledge Management. 
16.Van Den Hooff, B., \& De Ridder, J. A. (2004). Knowledge sharing in context: the influence of organizational commitment, communication climate and CMC use on knowledge sharing. Journal of Knowledge Management.

17.Wilkesmann, M., \& Wilkesmann, U. (2011). Knowledge transfer is an interaction between experts and novices supported by technology. Vine.

18.Zhang, Z. (2005). Managing knowledge assets in organizations: Role of incentives and information systems. The University of Pennsylvania. 